Article

\title{
Catalytic conversion of Jerusalem artichoke tuber into hexitols using the bifunctional catalyst $\mathrm{Ru} /\left(\mathrm{AC}^{\left.-\mathrm{SO}_{3} \mathrm{H}\right)}\right.$
}

\author{
Likun Zhou a,b,十,ł, Zhenlei Li a,b,†, Jifeng Pang a, Mingyuan Zheng a, Aiqin Wang a,\#, Tao Zhang a,* \\ a Dalian Institute of Chemical Physics, Chinese Academy of Sciences, Dalian 116023, Liaoning, China \\ b University of Chinese Academy of Sciences, Beijing 100049, China
}

A R T I C L E I N F O

Article history:

Received 17 April 2015

Accepted 3 June 2015

Published 20 October 2015

\section{Keywords:}

Jerusalem artichoke tuber

Hexitols

Bifunctional catalysts

Hydrolysis

Hydrogenation

Ruthenium

Sulfonation

\begin{abstract}
A B S T R A C T
Jerusalem artichoke tuber (JAT) was employed as a feedstock for production of hexitols under mild conditions over a sulfonated activated carbon supported $\mathrm{Ru}$ catalyst $\left(\mathrm{Ru} /\left(\mathrm{AC}_{-} \mathrm{SO}_{3} \mathrm{H}\right)\right)$. In comparison with conventional $\mathrm{Ru} / \mathrm{AC}$ catalyst, the sulfonation process of the carbon support was observed to create abundant surface acid groups, which in turn function as the anchoring sites for Ru nanoparticles, thus increasing the dispersion of Ru. Consequently, the bifunctional $\mathrm{Ru} /\left(\mathrm{AC}^{-} \mathrm{SO}_{3} \mathrm{H}\right)$ catalyst displayed significantly enhanced activity in one-pot production of hexitols from JAT; the hexitols yield achieved $92.6 \%$ over the $3 \% \mathrm{Ru} /\left(\mathrm{AC}_{-} \mathrm{SO}_{3} \mathrm{H}\right)$ catalyst when the reaction was conducted at $373 \mathrm{~K}$ and $6 \mathrm{MPa} \mathrm{H}_{2}$ for $3 \mathrm{~h}$. The stability of the catalyst was also investigated, which showed a decreasing trend in the yield of sorbitol with the run number due to poisoning of Ru surface by the impurity in the JAT feedstock. In contrast, when pure inulin was used as the feedstock, the catalyst presented excellent stability in the successive four runs.
\end{abstract}

(C) 2015, Dalian Institute of Chemical Physics, Chinese Academy of Sciences. Published by Elsevier B.V. All rights reserved.

\section{Introduction}

Hexitols including mannitol and sorbitol are important chemicals derived from biomass and are regarded as the optimal platform chemicals for biorefinery applications [1]. Hexitols are extensively used as sweeteners for the food industry. Additionally, they are also widely used as chemicals for the production of fuels and chemicals [2-5]. Generally, mannitol and sorbitol are produced by the hydrogenation of fructose and glucose using Raney Ni catalysts. Approximately $7 \times 10^{5}$ tons of hexitols are produced annually [6,7]. Nevertheless, the feedstock of this process is monosugars, which is competing with the food industry. Therefore, it is highly desirable to search for non-food routes for production of hexitols.

In the past decade, catalytic conversion of cellulose into hexitols has attracted significant attention [8-10]. In 2006, Fukuoka et al. [11] first reported $\mathrm{Pt} / \mathrm{Al}_{2} \mathrm{O}_{3}$-catalyzed conversion of cellulose into hexitols with yields of $31 \%$ at $463 \mathrm{~K}$. Further research by Liu et al. [12] employed hot water to produce protons in situ to obtain increased hexitol yields over a $\mathrm{Ru} / \mathrm{C}$ catalyst at $518 \mathrm{~K}$. The catalytic conversion of cellulose into hexitols is a cascade reaction, involving the hydrolysis of cellulose and the resultant sugars (glucose and fructose) hydrogenation, which necessitates the employment of bifunctional catalysts. Following the pioneering work of Fukuoka et al. [13-21], various bifunctional catalysts have been developed towards the

\footnotetext{
† These authors contributed equally to this work

* Corresponding author. Tel: +86-411-84379015; Fax: +86-411-84691570; E-mail: taozhang@dicp.ac.cn

\# Corresponding author. Tel: +86-411-84379348; Fax: +86- 411-84685940; E-mail: aqwang@dicp.ac.cn

${ }^{\ddagger}$ Present address is CNOOC Tianjing Chemical Research \& Design Institute.

This work was supported by the National Natural Science Foundation of China $(21176235,21306191$ and 21376239$)$.
}

DOI: 10.1016/S1872-2067(15)60933-0 | http://www.sciencedirect.com/science/journal/18722067 | Chin. J. Catal., Vol. 36, No. 10, October 2015 
improvement of hexitol yields. Although cellulose has advantages of being a non-edible and abundant resource, there still remains a great challenge for the large-scale production of hexitols from cellulose. First, the task to separate cellulose from raw lignocellulose materials is arduous and the lignin component often significantly hinders the conversion of cellulose [22]. Second, the abundance of hydrogen bonds together with the crystalline nature of cellulose makes it difficult to degrade under milder conditions [23]. Therefore, searching for an alternative to cellulose as a sustainable feedstock for the production of hexitols is highly desired.

Jerusalem artichoke is an important economic energy crop, which is fast-growing and requires relatively low inputs in terms of pesticides, fertilizer and water [24]. Widely cultivated in the north of China, the Jerusalem artichoke is strongly adaptable and yields high productivity. Inulin is the major component of the Jerusalem artichoke tuber (JAT), which is a mixture of linear $\beta$-(2-1)-linked fructose chains possessing a terminal glycopyranose unit at the reducing end. In difference to the rigid structure of cellulose, JAT is composed of low degree polymerized amorphous fructose and glucose, which can be converted easily at relatively mild conditions with high efficiency. Such features renders JAT as an ideal feedstock candidate for biorefinery applications in China [25-27].

In this work, we developed a bifunctional catalyst, Ru nanoparticles supported on sulfonated carbon, for the efficient conversion of JAT to hexitols. By characterizing the catalyst surface acidity and $\mathrm{Ru}$ dispersion, correlation of reactivity to the properties of the catalysts was observed. The catalysts were highly active for the one pot conversion of JAT to hexitols under mild reaction conditions and the stability is dependent on the feedstock purity.

\section{Experimental}

\subsection{Composition analysis of JAT}

The JAT was received from Wafangdian in Dalian, China. Prior to use, the artichoke was chipped and dried at $60{ }^{\circ} \mathrm{C}$ for $12 \mathrm{~h}$. Thereafter the artichoke was milled into powders targeting a mesh size of $<60$ mesh.

The reducing sugars in the JAT were analyzed via a 3,5-dinitrosalicylic acid method as described elsewhere [28].

\subsection{Catalyst preparation}

AC- $\mathrm{SO}_{3} \mathrm{H}$ was prepared according to our previous report [29]. In detail, $1 \mathrm{~g}$ activated carbon (AC; Norit) was added to 15 mL concentrated $\mathrm{H}_{2} \mathrm{SO}_{4}$ (98\%) in an in-house fabricated glass tube prior to the carbon being sulfonated at $523 \mathrm{~K}$ for $24 \mathrm{~h}$ under $\mathrm{N}_{2}(10 \mathrm{~mL} / \mathrm{min})$. After cooling, dilution and filtering, the as-prepared $\mathrm{AC}-\mathrm{SO}_{3} \mathrm{H}$ was washed with copious amounts of hot water until no detection of $\mathrm{SO}_{4}{ }^{2-}$ anions in the $\mathrm{Ba}\left(\mathrm{NO}_{3}\right)_{2}$ filtrate.

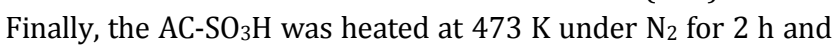
then washed thoroughly with water until no $\mathrm{SO}_{4}{ }^{2-}$ was detected in the filtrate.

The $\mathrm{Ru} /\left(\mathrm{AC}^{\mathrm{SO}}{ }_{3} \mathrm{H}\right)$ catalyst was prepared via an impregna- tion method. Taking $1 \% \mathrm{Ru} /\left(\mathrm{AC}_{-} \mathrm{SO}_{3} \mathrm{H}\right)$ as an example, $1 \mathrm{~g}$ $\mathrm{AC}-\mathrm{SO}_{3} \mathrm{H}$ support was impregnated with $3 \mathrm{~mL} \mathrm{RuCl}_{3}$ solution containing $0.01 \mathrm{~g} \mathrm{Ru}$, followed by drying at $393 \mathrm{~K}$ for $12 \mathrm{~h}$. The sample was then reduced under $\mathrm{H}_{2}$ at $473 \mathrm{~K}$ for $1 \mathrm{~h}$.

\subsection{Catalyst characterization}

The surface area and pore size distribution of the supports and catalysts were determined by $\mathrm{N}_{2}$ adsorption-desorption at 77 K using a Micromeritics ASAP 2010 apparatus. Prior to measurements, the samples were degassed at $523 \mathrm{~K}$ for $3 \mathrm{~h}$.

The contents of $\mathrm{Ru}$ and $-\mathrm{SO}_{3} \mathrm{H}$ in the catalysts were measured with Inductive Couple Plasma Atomic Emission Spectrometer (ICP-AES, Thermal Scientific-IRIS Intrepid II XSP). Prior to the measurements, the samples were dissolved with aqua regia in a microwave digestion system at $483 \mathrm{~K}$ for 10 $\min$.

The acid density of the catalysts were measured following a titration method [30]. Typically, $0.05 \mathrm{~g}$ catalyst was added to 20 $\mathrm{mL}$ of $\mathrm{NaOH}$ aqueous solution $(0.01 \mathrm{~mol} / \mathrm{L})$. After stirring the mixture at $298 \mathrm{~K}$ for $60 \mathrm{~min}$, the solution was separated from the solid by a $0.45-\mu \mathrm{m}$ membrane syringe filter. The supernatant solution was titrated with $\mathrm{HCl}$ aqueous solution $(0.01$ mol/L) using phenolphthalein as an indicator.

Transmission electron microscopy (TEM) analysis was performed on a JEM-2000EX (JEOL) microscope. Before analysis, the catalysts were dispersed in an ethanol solution and ultrasonicated before depositing the suspension drop wise onto a copper grid.

\subsection{Catalyst testing}

The reaction of the catalytic conversion of JAT into hexitols was conducted in a stainless steel autoclave (Parr Instrument Company, $100 \mathrm{~mL}$ ) at a designated temperature with $6 \mathrm{MPa}$ initial $\mathrm{H}_{2}$ pressure. Before reaction, the polysugar in JAT was extracted with hot water at $363 \mathrm{~K}$ for $10 \mathrm{~min}$. Thereafter, the JAT saccharides solution ( $25 \mathrm{~mL})$, catalyst $(0.3 \mathrm{~g})$ and water $(25$ $\mathrm{mL}$ ) were charged into the autoclave and stirred (960 r/min). For comparison, fructose and inulin (provided by J\&K) were also employed as feedstock for catalytic conversion with similar conditions. After reaction, the liquid-phase products were filtered and analyzed by HPLC (Agilent 1200, Shodex Sugar SC1011 column, differential refractive index detector).

Control experiments were conducted in a 300-mL Parr autoclave. Typically, $100 \mathrm{~mL}$ JAT saccharides solution and $1.2 \mathrm{~g}$ catalyst were loaded in the autoclave with $100 \mathrm{~mL}$ water before charging the autoclave with $6 \mathrm{MPa} \mathrm{N}_{2}$ or $\mathrm{H}_{2}$. Finally, the autoclave was heated to $373 \mathrm{~K}$ and maintained for a designed time.

The yields of polyols were calculated as: yield $(\%)=($ mole of carbon in the products) / (mole of carbon in the feedstock) $\times$ $100 \%$.

\section{Results and discussion}

\subsection{The composition ofJAT}


The composition of JAT is highly dependent on numerous factors such as: geographical location where it is farmed, fertilization and the harvest season [31]. As shown in Fig. 1, the major component of JAT is inulin, which accounts for $57.0 \%$. Meanwhile, the existence of monosugars JAT is evident. The content of fructose and glucose are $12.0 \%$ and $4.5 \%$ respectively. Total sugars in JAT reach $73.5 \%$, including inulin, fructose and glucose. In addition to sugar content, the rest of the make-up consists of $1.7 \%$ ashes and $24.8 \%$ other components such as cellulose, lignin, protein and amino acid [32,33]. To avoid the negative effect of lignin [34,35], JAT was first extracted with hot water with the extracted liquid-containing inulin, fructose, glucose and some soluble impurities-used as the feedstock for the reaction.

\subsection{Catalyst and support properties}

The properties of the bare supports and the final catalysts are summarized in Table 1 . The AC has a surface area of 768 $\mathrm{m}^{2} / \mathrm{g}$ and an acid density of $0.21 \mathrm{mmol} / \mathrm{g}$. The acidity of the AC can be attributed to the surface $-\mathrm{OH}$ and $-\mathrm{COOH}$ groups. After sulfonation at $523 \mathrm{~K}$, the surface area of the resulting $\mathrm{AC}-\mathrm{SO}_{3} \mathrm{H}$ increased to $1020 \mathrm{~m}^{2} / \mathrm{g}$ with the microporous surface area being reduced from 477 to $376 \mathrm{~m}^{2} / \mathrm{g}$ indicating that the sulfonation process not only removed the impurities that block the pores in the AC but further enhanced the accessibility of the pores by oxidizing the surface carbon of AC. Additionally, the

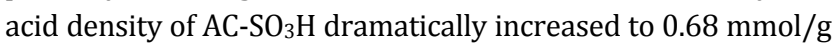
containing $0.10 \mathrm{mmol} / \mathrm{g}$ of $-\mathrm{SO}_{3} \mathrm{H}$ groups. This result suggested that the high temperature sulfonation process anchored $-\mathrm{SO}_{3} \mathrm{H}$ groups onto the surface of $\mathrm{AC}$ and introduced more surface acidic groups such as $-\mathrm{COOH}$ and $-\mathrm{OH}$ by oxidation reaction.

With the creation of abundant acidic groups by sulfonation, $\mathrm{Ru}$ was further loaded on the $\mathrm{AC}-\mathrm{SO}_{3} \mathrm{H}$ support at varying concentrations. The AC support was also loaded with Ru for comparison purposes. As shown in Table 1, the loading of Ru led to a slight decrease in the surface area, both for AC and the $\mathrm{AC}-\mathrm{SO}_{3} \mathrm{H}$ supports. The actual loadings of $\mathrm{Ru}$, determined by ICP-AES, were $\sim 1.5$ times higher than the nominated values because of the methanation of carbon supports during the reduction process [36]. Quite different from $1 \% \mathrm{Ru} / \mathrm{AC}$ where the

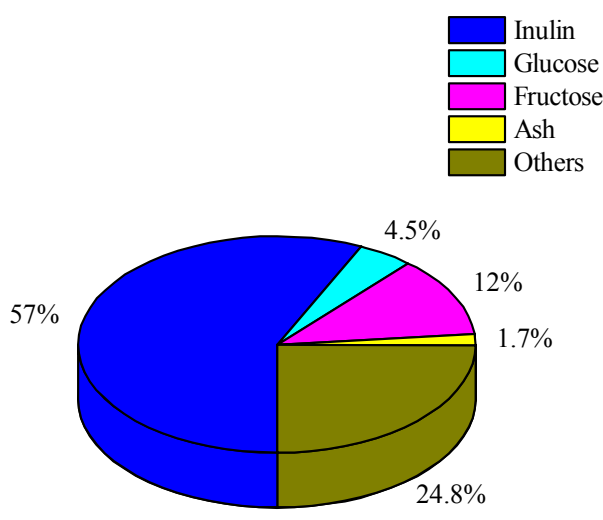

Fig. 1. The composition of the as-received JAT.
Table 1

Support and catalyst properties.

\begin{tabular}{lrcccc}
\hline Catalyst & \multicolumn{1}{c}{$\begin{array}{c}S_{\text {BET }} \\
\left(\mathrm{m}^{2} / \mathrm{g}\right)\end{array}$} & $\begin{array}{c}S_{\text {micro }} \\
\left(\mathrm{m}^{2} / \mathrm{g}\right)\end{array}$ & $\begin{array}{c}\text { Ru loading a } \\
(\text { wt\% })\end{array}$ & $\begin{array}{c}-\mathrm{SO}_{3} \mathrm{H}^{\mathrm{a}} \\
(\mathrm{mmol} / \mathrm{g})\end{array}$ & $\begin{array}{c}\text { Acid density b } \\
(\mathrm{mmol} / \mathrm{g})\end{array}$ \\
\hline $\mathrm{AC}$ & 768 & 477 & - & - & 0.21 \\
$\mathrm{AC}-\mathrm{SO}_{3} \mathrm{H}$ & 1020 & 376 & - & 0.10 & 0.68 \\
$1 \% \mathrm{Ru} / \mathrm{AC}$ & 709 & 443 & 1.6 & - & 0.10 \\
$1 \% \mathrm{Ru} /\left(\mathrm{AC}^{\left.-\mathrm{SO}_{3} \mathrm{H}\right)}\right.$ & 884 & 316 & 1.6 & 0.09 & 0.84 \\
$2 \% \mathrm{Ru} /\left(\mathrm{AC}^{\left.-\mathrm{SO}_{3} \mathrm{H}\right)}\right.$ & 905 & 306 & 3.4 & 0.07 & 0.88 \\
$3 \% \mathrm{Ru} /\left(\mathrm{AC}^{\left.-\mathrm{SO}_{3} \mathrm{H}\right)}\right.$ & 866 & 268 & 4.3 & 0.10 & 0.91 \\
\hline
\end{tabular}

a Measured by ICP-AES.

$\mathrm{b}$ Determined by titration.

loading of Ru caused the decrease of acid density from 0.21 to $0.10 \mathrm{mmol} / \mathrm{g}$, the loading of $\mathrm{Ru}$ on the $\mathrm{AC}-\mathrm{SO}_{3} \mathrm{H}$ support brought about a significant increase in the surface acid density, suggesting there is a synergistic effect between $-\mathrm{SO}_{3} \mathrm{H}$ groups and Ru. Previously, Fukuoka et al. $[37,38]$ reported $\mathrm{RuO}_{2} \cdot 2 \mathrm{H}_{2} \mathrm{O}$ as being the state of $\mathrm{Ru}$ on the carbon material after reducing with $\mathrm{H}_{2}$ and subsequent passivation at room temperature and the formed $\mathrm{RuO}_{2} \cdot 2 \mathrm{H}_{2} \mathrm{O}$ could promote cellulose hydrolysis to generate acidic properties. However, in situ Raman spectra of the $1 \% \mathrm{Ru} /\left(\mathrm{AC}_{-} \mathrm{SO}_{3} \mathrm{H}\right)$ catalyst showed that $\mathrm{Ru}$ existed as the metallic state, either for the freshly reduced sample or for passivated samples, thus the contribution from $\mathrm{RuO}_{2} \cdot 2 \mathrm{H}_{2} \mathrm{O}$ can be safely excluded.

The $1 \% \mathrm{Ru} / \mathrm{AC}$ and $1 \% \mathrm{Ru} /\left(\mathrm{AC}-\mathrm{SO}_{3} \mathrm{H}\right)$ catalysts were further characterized by TEM. As shown in Fig. 2, there are no discernable $\mathrm{Ru}$ particles visible under the given magnification of the TEM micrographs, indicating Ru particles were highly dispersed on the two supports. The dispersion of $\mathrm{Ru}$ was further measured by $\mathrm{CO}$ chemisorption with $\mathrm{CO}$ uptake values of 0.05 and $0.18 \mathrm{mmol} / \mathrm{g}_{\text {cat, }}$ which corresponded to a $\mathrm{Ru}$ dispersion of $30.9 \%$ and $74.2 \%$ for $1 \% \mathrm{Ru} / \mathrm{AC}$ and $1 \% \mathrm{Ru} /\left(\mathrm{AC}^{\left.-\mathrm{SO}_{3} \mathrm{H}\right)}\right.$ catalysts respectively. Evidently, the sulfonation process of the carbon support greatly improved the dispersion of $\mathrm{Ru}$ because of the creation of new additional anchoring sites.

\subsection{Catalytic performance}

The catalytic conversion of JAT into hexitols is a cascade reaction. JAT is firstly hydrolyzed into sugars and then hydrogenated into hexitols. Bifunctional catalysts are therefore required for the high production of hexitols from JAT. The reaction was performed at mild conditions ( $\left.373 \mathrm{~K}, 6 \mathrm{MPa} \mathrm{H}_{2}, 5 \mathrm{~h}\right)$. Table 2

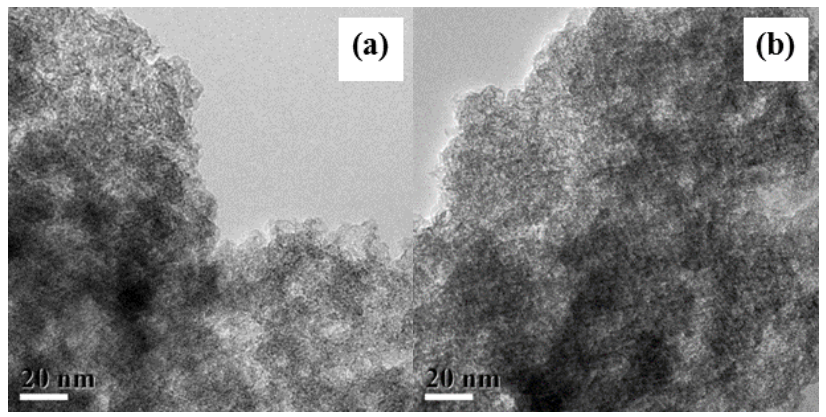

Fig. 2. TEM images of $1 \% \mathrm{Ru} / \mathrm{AC}(\mathrm{a})$ and $1 \% \mathrm{Ru} /\left(\mathrm{AC}^{\left.-\mathrm{SO}_{3} \mathrm{H}\right)}\right.$ (b) catalysts. 
Table 2

Sugar and hexitol yield for JAT conversion over various catalysts a.

\begin{tabular}{|c|c|c|c|c|c|c|c|}
\hline \multirow{2}{*}{ Feedstock } & \multirow{2}{*}{ Catalyst } & \multicolumn{6}{|c|}{ Yield (\%) b } \\
\hline & & Mannitol & Sorbitol & Hexitols & Fructose & Glucose & Sucrose \\
\hline JAT & $1 \% \mathrm{Ru} / \mathrm{AC}$ & 19.2 & 33.5 & 52.7 & 14.8 & 6.5 & 16.1 \\
\hline JAT & $1 \% \mathrm{Ru} /\left(\mathrm{AC}^{\left.-\mathrm{SO}_{3} \mathrm{H}\right)}\right.$ & 29.5 & 54.6 & 84.1 & 4.6 & 5.5 & 5.3 \\
\hline JAT & $2 \% \mathrm{Ru} /\left(\mathrm{AC}-\mathrm{SO}_{3} \mathrm{H}\right)$ & 30.9 & 60.4 & 91.3 & 0.6 & 0.6 & 2.4 \\
\hline JAT & $3 \% \mathrm{Ru} /\left(\mathrm{AC}^{\left.-\mathrm{SO}_{3} \mathrm{H}\right)}\right.$ & 31.5 & 61.1 & 92.6 & 0.0 & 0.0 & 2.2 \\
\hline Fructose & $1 \% \mathrm{Ru} / \mathrm{AC}$ & 39.4 & 56.4 & 95.8 & 0.0 & 0.0 & 0.0 \\
\hline Fructose & $1 \% \mathrm{Ru} /\left(\mathrm{AC}-\mathrm{SO}_{3} \mathrm{H}\right)$ & 41.3 & 55.3 & 96.6 & 0.0 & 0.0 & 0.0 \\
\hline Inulin & $1 \% \mathrm{Ru} / \mathrm{AC}$ & 39.3 & 51.4 & 90.7 & 0.0 & 0.0 & 4.1 \\
\hline Inulin & $1 \% \mathrm{Ru} /\left(\mathrm{AC}^{\left.-\mathrm{SO}_{3} \mathrm{H}\right)}\right.$ & 44.8 & 51.0 & 95.8 & 0.0 & 0.0 & 3.7 \\
\hline
\end{tabular}

a Typical reaction conditions: JAT $25 \mathrm{~mL}$, inulin or fructose $0.5 \mathrm{~g}$, catalyst $0.3 \mathrm{~g}$, distilled water ( $25 \mathrm{~mL}$ for JAT, $50 \mathrm{~mL}$ for inulin and fructose), $373 \mathrm{~K}, 6$ $\mathrm{MPa} \mathrm{H}_{2}, 5$ h.

lists the yields of sugars and hexitols from JAT catalyzed with different catalysts. When $1 \% \mathrm{Ru} / \mathrm{AC}$ was employed as the catalyst, the yield of hexitols was $52.7 \%$ including $19.2 \%$ mannitol and $33.5 \%$ sorbitol. In addition, sugars including fructose $(14.8 \%)$, glucose $(6.5 \%)$ and sucrose $(16.1 \%)$ were also produced, indicating that the hydrogenation capability of the $1 \% \mathrm{Ru} / \mathrm{AC}$ catalyst was not sufficiently adequate. In contrast, the $1 \% \mathrm{Ru} /\left(\mathrm{AC} \mathrm{SO}_{3} \mathrm{H}\right)$ catalyst yielded dramatically reduced sugar production while the hexitol yield significantly increased to $84.1 \%$. This improvement can be attributed to the enhanced acid density and $\mathrm{Ru}$ dispersion on the surface of the $1 \% \mathrm{Ru} /\left(\mathrm{AC}^{\left.-\mathrm{SO}_{3} \mathrm{H}\right)}\right.$ catalyst, as shown in Table 1 . The high density of acid groups of $1 \% \mathrm{Ru} /\left(\mathrm{AC}-\mathrm{SO}_{3} \mathrm{H}\right)$ catalysts, including $-\mathrm{OH},-\mathrm{COOH}$ and $-\mathrm{SO}_{3} \mathrm{H}$, promoted JAT hydrolysis while the highly dispersed $\mathrm{Ru}$ centers catalyzed the hydrogenation of sugars instantly upon their production, as a result, the hexitol yield was enhanced greatly. Moreover, the hydrogenation capability of $\mathrm{Ru} /\left(\mathrm{AC}-\mathrm{SO}_{3} \mathrm{H}\right)$ catalysts was further improved as a function of increasing Ru loading. For instance, when the nominal $\mathrm{Ru}$ loading was raised from $1 \%$ to $2 \%$ (corresponding to actual $\mathrm{Ru}$ loadings of $1.6 \%$ and $3.4 \%$ respectively), the hexitol yield increased from $84.1 \%$ to $91.3 \%$ whilst the total sugar yield decreased to less than 5\%. Further increasing the $\mathrm{Ru}$ loading to the nominal value of $3 \%$ led to a slight increase of the hexitol yield (92.6\%). To the best of our knowledge, this hexitol yield is the highest reported hitherto for one pot conversion of JAT to hexitols and comparable to that obtained from inulin conversion previously reported by Peters et al. [39].

Differences from JAT, when inulin and fructose were used as the feedstock, are observed as higher hexitol yields are obtainable over both $\mathrm{Ru} / \mathrm{AC}$ and $\mathrm{Ru} /\left(\mathrm{AC}-\mathrm{SO}_{3} \mathrm{H}\right)$ catalysts. Furthermore, when fructose was employed as the feedstock the two catalysts performed similarly, while $1 \% \mathrm{Ru} / \mathrm{AC}$ was vastly inferior to the $1 \% \mathrm{Ru} /\left(\mathrm{AC}_{-} \mathrm{SO}_{3} \mathrm{H}\right)$ counterpart when inulin was the feedstock. This result suggests that the hydrolysis of inulin and JAT may be the rate-determining step in the whole conversion process, while the acid sites created during the sulfonation process could promote this rate-determining step.

\subsection{Reaction pathway}

To elucidate the reaction pathway from JAT to hexitols, we monitored the product distribution as a function of reaction time under $\mathrm{N}_{2}$ and $\mathrm{H}_{2}$ atmospheres respectively. As shown in Fig. 3, when the reaction proceeded under $\mathrm{N}_{2}$, fructose and glucose were the major products during the whole reaction process with only a minor sucrose yield. Evidently, under a $\mathrm{N}_{2}$ atmosphere the hydrolysis of JAT was the main reaction pathway. Additionally, fructose achieved its plateau at shorter time-on-stream over the $1 \% \mathrm{Ru} /\left(\mathrm{AC}^{-} \mathrm{SO}_{3} \mathrm{H}\right)$ catalyst than that over $1 \% \mathrm{Ru} / \mathrm{AC}$, which is consistent with the much higher acid density in the former catalyst. In contrast, when the reaction was conducted under a $\mathrm{H}_{2}$ atmosphere (Fig. 4), sugars (fructose $>$ glucose $>$ sucrose) underwent maxima within $1 \mathrm{~h}$ before starting to decrease with time, meanwhile the hydrogenation products (mannitol and sorbitol) increased steadily with time, indicating that sugars are merely intermediates under the $\mathrm{H}_{2}$ atmosphere. Again, the higher acid density and hydrogenation activity of the $1 \% \mathrm{Ru} /\left(\mathrm{AC}^{\left.-\mathrm{SO}_{3} \mathrm{H}\right)}\right.$ catalyst is attributable to the sugars reaching their maxima in a shorter duration time and their rapid consumption. Based on these results, the reaction pathway from JAT to hexitols can be expressed as follows:

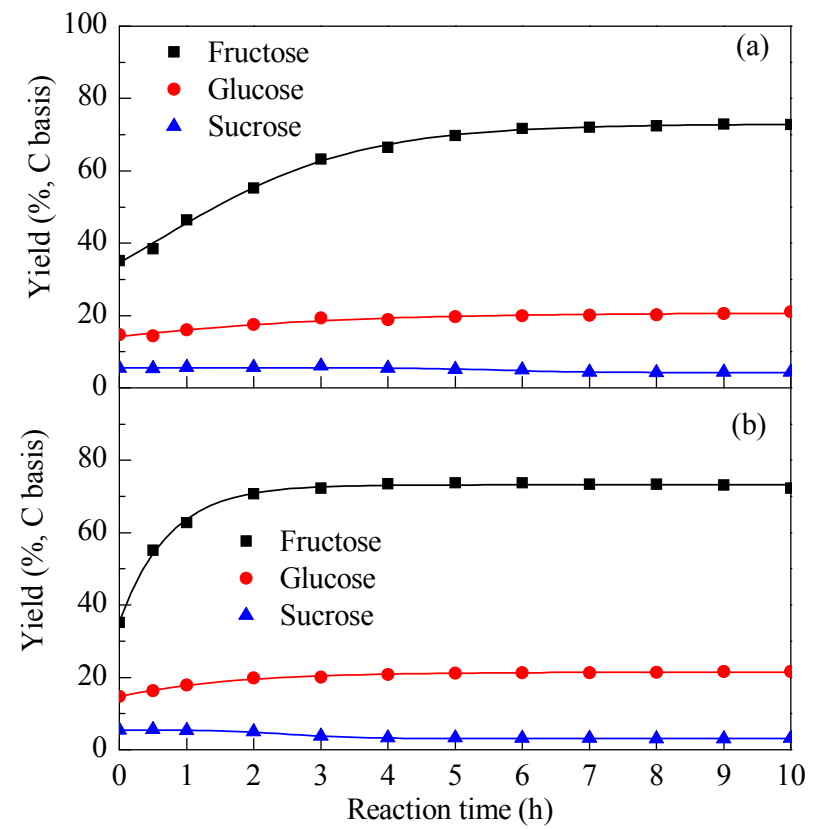

Fig. 3. Product distribution for JAT conversion under $\mathrm{N}_{2}$ as a function of reaction time over $1 \% \mathrm{Ru} / \mathrm{AC}(\mathrm{a})$ and $1 \% \mathrm{Ru} /\left(\mathrm{AC}^{-} \mathrm{SO}_{3} \mathrm{H}\right)$ (b) catalysts. 


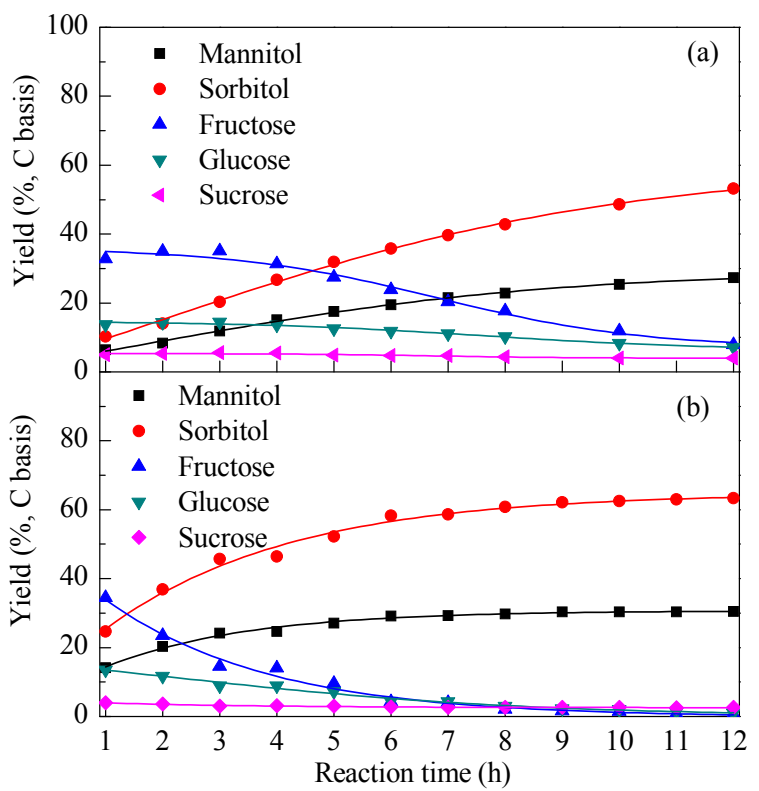

Fig. 4. Product distribution for JAT conversion under $\mathrm{H}_{2}$ as a function of reaction time over $1 \% \mathrm{Ru} / \mathrm{AC}(\mathrm{a})$ and $1 \% \mathrm{Ru} /\left(\mathrm{AC}^{\left.-\mathrm{SO}_{3} \mathrm{H}\right)}\right.$ (b) catalysts.

$$
\begin{gathered}
\text { JAT } \underset{\mathrm{H}_{2} \mathrm{O}}{\stackrel{\mathrm{H}^{+}}{\longrightarrow}} \text { Fructose }+ \text { Glucose }+ \text { Sucrose } \\
\text { Sugars } \underset{\mathrm{H}_{2}}{\stackrel{\mathrm{Ru}}{\longrightarrow}} \text { Mannitol + Sorbitol }
\end{gathered}
$$

To obtain a high hexitol yield, a suitable balance between the acid sites and the hydrogenation sites is required and sulfonation of the carbon support before loading $\mathrm{Ru}$ is a crucial prerequisite step to achieve this requirement.

\subsection{Catalysts stability}

Because $\mathrm{Ru} /\left(\mathrm{AC}^{-} \mathrm{SO}_{3} \mathrm{H}\right)$ catalysts exhibited superior activity for the one pot production of hexitols form JAT, the $1 \% \mathrm{Ru} /\left(\mathrm{AC}-\mathrm{SO}_{3} \mathrm{H}\right)$ catalyst was further investigated for its reaction stability and recycling performance. As shown in Fig. 5, when JAT was used as feedstock, the hexitol yield gradually decreased from $87 \%$ to $55 \%$ during the successive four runs, concurrently the yield of sugars increased. ICP analysis of the liquid after the reaction indicated that no leaching of $\mathrm{Ru}$ occurred during the reaction. This result suggests that the hydrogenation metal sites are poisoned gradually by the impurities (e.g., protein, inorganic salts, see Fig. 1) in the JAT feedstock [40]. CO chemisorption of the used catalyst after three runs indicated the dispersion of $\mathrm{Ru}$ decreased significantly from $74.2 \%$ to $17.8 \%$, confirming covering of the Ru active sites by impurities of the JAT feedstock. In contrast, when inulin was used as feedstock, the stability of the catalyst improved greatly; the hexitol yield only marginally decreased after four runs (Fig 5(b)). The difference between inulin and JAT was the impurity content; the former is the main component of the latter and without any impurities. Therefore, for the $1 \% \mathrm{Ru} /\left(\mathrm{AC}^{\left.-\mathrm{SO}_{3} \mathrm{H}\right)}\right.$ catalyst, the most suitable feedstock is inulin, which is easily obtained from JAT through extraction by hot water or dilute acid.

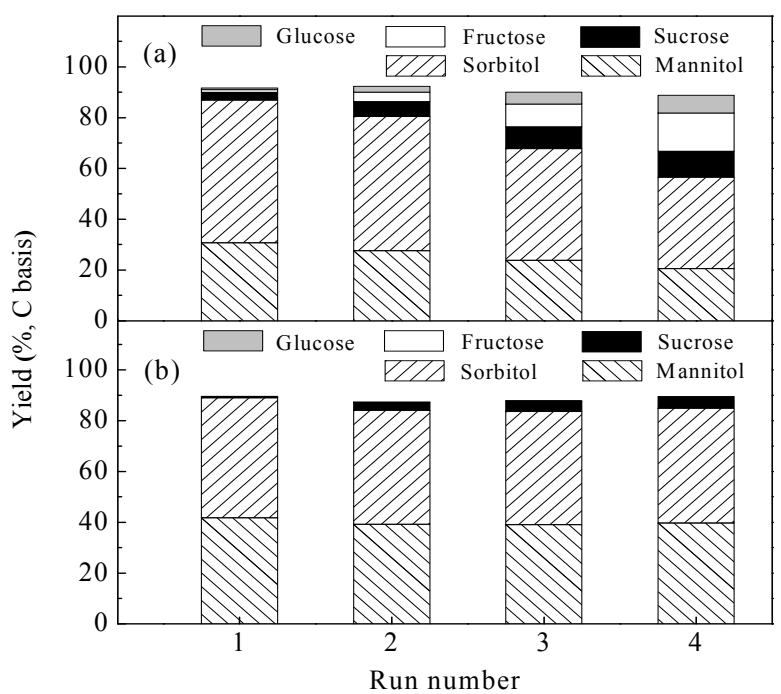

Fig. 5. The reusability of the $1 \% \mathrm{Ru} /\left(\mathrm{AC}^{\left.-\mathrm{SO}_{3} \mathrm{H}\right)}\right.$ catalyst for JAT (a) and inulin (b) conversion. Reaction conditions: $413 \mathrm{~K}, 6 \mathrm{MPa} \mathrm{H}$, 2 h.

\section{Conclusions}

Bifunctional catalysts $\mathrm{Ru} /\left(\mathrm{AC}-\mathrm{SO}_{3} \mathrm{H}\right)$ have been developed for the one-pot conversion of JAT into hexitols. In comparison with the $\mathrm{Ru} / \mathrm{AC}$ catalyst, the sulfonation process introduced an abundance of $-\mathrm{OH},-\mathrm{COOH}$ and $-\mathrm{SO}_{3} \mathrm{H}$ groups on the support surface, which not only provided acidity but also functioned as anchoring sites for Ru nanoparticles. Thus, the dispersion of $\mathrm{Ru}$ was significantly enhanced. As a consequence, the hexitol yields dramatically improved. After $5 \mathrm{~h}$ of reaction at $373 \mathrm{~K}$, the hexitol yields reached $92.6 \%$ over the $3 \% \mathrm{Ru} /\left(\mathrm{AC} \mathrm{SO}_{3} \mathrm{H}\right)$ catalyst. The stability of the $\mathrm{Ru} /\left(\mathrm{AC}-\mathrm{SO}_{3} \mathrm{H}\right)$ catalyst was critically dependent on the feedstock purity. The level of impurities in JAT resulted in catalytic poisoning, while using inulin as the feedstock allowed recycling of the catalyst during four successive runs with only a slight decrease in the hexitol yield.

\section{References}

[1] Bozell J J, Petersen G R. Green Chem, 2010, 12: 539

[2] Huber G W, Cortright R D, Dumesic J A. Angew Chem Int Ed, 2004, 43: 1549

[3] Rose M, Palkovits R. ChemSusChem, 2012, 5: 167

[4] Vilcocq L, Cabiac A, Especel C, Lacombe S, Duprez D. Catal Today, 2012, 189: 117

[5] Zhang J, Li J B, Wu S B, Liu Y. Ind Eng Chem Res, 2013, 52: 11799

[6] Kusserow B, Schimpf S, Claus P. Adv Synth Catal, 2003, 345: 289

[7] Climent M J, Corma A, Iborra S. Green Chem, 2011, 13: 520

[8] Xiao Z H, Jin S H, Pang M, Liang C H. Green Chem, 2013, 15: 891

[9] Kobayashi H, Fukuoka A. Green Chem, 2013, 15: 1740

[10] Ma J P, Yu W Q, Wang M, Jia X Q, Lu F, Xu J. Chin J Catal (马继平, 于 维强, 王敏, 贾秀全, 路芳, 徐杰. 催化学报), 2013, 34: 492

[11] Fukuoka A, Dhepe P L. Angew Chem Int Ed, 2006, 45: 5161

[12] Luo C, Wang S A, Liu H C. Angew Chem Int Ed, 2007, 46: 7636

[13] Deng W P, Tan X S, Fang W H, Zhang Q H, Wang Y. Catal Lett, 2009, 133: 167

[14] Ding L N, Wang A Q, Zheng M Y, Zhang T. ChemSusChem, 2010, 3: 


\title{
Graphical Abstract
}

Chin. J. Catal., 2015, 36: 1694-1700 doi: 10.1016/S1872-2067(15)60933-0

\section{Catalytic conversion of Jerusalem artichoke tuber into hexitols using the bifunctional catalyst $\mathrm{Ru} /\left(\mathrm{AC}^{\left.-\mathrm{SO}_{3} \mathrm{H}\right)}\right.$}

Likun Zhou, Zhenlei Li, Jifeng Pang, Mingyuan Zheng, Aiqin Wang *, Tao Zhang*

Dalian Institute of Chemical Physics, Chinese Academy of Sciences; University of Chinese Academy of Sciences

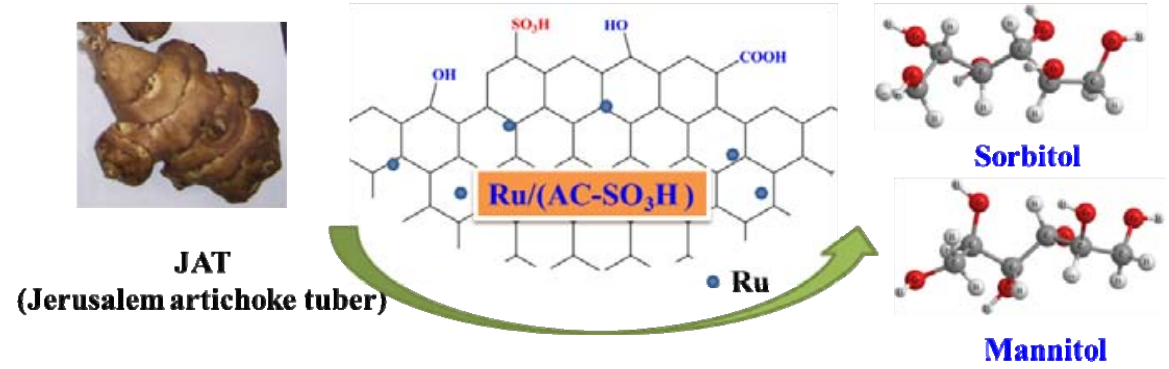

Bifunctional catalysts $\mathrm{Ru} /\left(\mathrm{AC}_{\mathrm{SO}} \mathrm{H}\right)$ were developed for the conversion of JAT into hexitols. The hydrolysis and hydrogenation active sites were suitably tailored to achieve a hexitol yield of $92.6 \%$.

\section{8}

[15] Van De Vyver S, Geboers J, Dusselier M, Schepers H, Vosch T, Zhang L, Van Tendeloo G, Jacobs P A, Sels B F. ChemSusChem, 2010, 3: 698

[16] Geboers J, Van De Vyver S, Carpentier K, de Blochouse K, Jacobs P, Sels B. Chem Commun, 2010, 46: 3577

[17] Han J W, Lee H. Catal Commun, 2012, 19: 115

[18] Pang J F, Wang A Q, Zheng M Y, Zhang Y H, Huang Y Q, Chen X W, Zhang T. Green Chem, 2012, 14: 614

[19] Liang G F, Cheng H Y, Li W, He L M, Yu Y C, Zhao F Y. Green Chem, 2012, 14: 2146

[20] Li X T, Jiang Y J, Shuai L, Wang L L, Meng L Q, Mu X D. J Mater Chem, 2012, 22: 1283

[21] Chen J Z, Wang S P, Huang J, Chen L M, Ma L L, Huang X. ChemSusChem, 2013, 6: 1545

[22] Zhao X B, Zhang L H, Liu D H. Biofuels Bioprod Bioref, 2012, 6: 465

[23] Gallezot P. Chem Soc Rev, 2012, 41: 1538

[24] Liu Z X, Spiertz J H J, Sha J, Xue S, Xie G H. Agronomy J, 2012, 104: 1538

[25] Tian Y S, Zhao L X, Meng H B, Sun L Y, Yan J Y. Appl Energy, 2009, 86: $S 77$

[26] Zhou L K, Pang J F, Wang A Q, Zhang T. Chin J Catal (周立坤, 庞纪 峰, 王爱琴, 张涛. 催化学报), 2013, 34: 2041
[27] Zhou L K, Wang A Q, Li C Z, Zheng M Y, Zhang T. ChemSusChem, 2012, 5: 932

[28] Miller G L. Anal Chem, 1959, 31: 426

[29] Pang J F, Wang A Q Zheng M Y, Zhang T. Chem Commun, 2010, 46: 6935

[30] Wu Y, Fu Z, Yin D, Xu Q, Liu F, Lu C, Mao L. Green Chem, 2010, 12: 696

[31] Schorr-Galindo S, Guiraud J P. Bioresource Technol, 1997, 60: 15

[32] Bacon J S D, Edelman J. Biochem J, 1951, 48: 114

[33] Somda Z C, McLaurin W J, Kays S J. J Plant Nutr, 1999, 22: 1315

[34] Pang J F, Zheng M Y, Wang A Q, Zhang T. Ind Eng Chem Res, 2011, 50: 6601

[35] Wang A Q, Zhang T. Acc Chem Res, 2013, 46: 1377

[36] Ji N, Zhang T, Zheng M Y, Wang A Q, Wang H, Wang X D, Chen J G. Angew Chem Int Edt, 2008, 47: 8510

[37] Kobayashi H, Komanoya T, Hara K, Fukuoka A. ChemSusChem, 2010, 3: 440

[38] Komanoya T, Kobayashi H, Hara K, Chun W-J, Fukuoka A. Appl Catal A, 2011, 407: 188

[39] Heinen A W, Peters J A, Van Bekkum H. Carbohyd Res, 2001, 330: 381

[40] Yang F L, Liu Q S, Bai X F, Du Y G. Bioresource Technol, 2011, 102: 3424

\section{双功能催化剂 $\mathrm{Ru} /\left(\mathbf{A C}-\mathrm{SO}_{3} \mathrm{H}\right)$ 催化转化菊芋根茎制备六元醇}

\author{
周立坤 ${ }^{\mathrm{a}, \mathrm{b}, \dagger, \mathrm{f}}$, 李振雷 ${ }^{\mathrm{a}, \mathrm{b}, \dagger}$, 庞纪峰 ${ }^{\mathrm{a}}$, 郑明远 ${ }^{\mathrm{a}}$, 王爱琴 ${ }^{\mathrm{a}, \#}$, 张 涛, ${ }^{\mathrm{a}}$, \\ a国科学院大连化学物理研究所, 辽宁大连 116023 \\ ${ }^{\mathrm{b}}$ 中国科学院大学, 北京 100049
}

摘要: 甘露醇和山梨醇等六元醇是重要的多元醇, 广泛用于食品、医药和化工等领域, 尤其山梨醇被美国能源部定为一种重要的 平台化合物. 工业上, 六元醇通常由果糖、葡萄糖和蔗糖加氢得到, 此路线存在与人争粮争地的问题. 菊芋是一种来源广泛、价格 低廉的生物质资源, 它富含果糖基多糖(菊糖), 菊糖的含量占菊芋根茎干重的 $70 \%-90 \%$, 由生物质菊芋出发催化转化制备六元醇 具有重要意义.

由菊芋根茎催化转化制备六元醇是一个串联反应过程, 菊芋根茎先经过水解得到糖类, 然后经过加氢反应得到六元醇. 我们用 磺化活性炭 $\mathrm{AC}-\mathrm{SO}_{3} \mathrm{H}$ 代替 $\mathrm{AC}$ 载体以促进菊芋根茎水解反应. $\mathrm{AC}$ 经磺化后, 比表面积由原来的 768 增至 $1020 \mathrm{~m}^{2} / \mathrm{g}$, 酸强度由原来的 0.21 增至 $0.68 \mathrm{mmol} / \mathrm{g}$, 表明磺化过程不仅除去了 $\mathrm{AC}$ 中的杂质, 也在其表面固定了大量的 $-\mathrm{SO}_{3} \mathrm{H},-\mathrm{COOH},-\mathrm{OH}$ 等酸性基团. 透射电 
镜结果表明, $1 \% \mathrm{Ru} / \mathrm{AC}$ 和 $1 \% \mathrm{Ru} /\left(\mathrm{AC}-\mathrm{SO}_{3} \mathrm{H}\right)$ 催化剂上 $\mathrm{Ru}$ 高度分散. $\mathrm{CO}$ 化学吸附表明, 上述两种催化剂 $\mathrm{Ru}$ 的分散度分别为 $30.9 \%$ 和 $74.2 \%$, 表明 $\mathrm{AC}$ 经磺化后产生了更多的固定位点, 使得Ru可以更好地分散在载体上.

在温和条件下 $\left(100^{\circ} \mathrm{C}, 6 \mathrm{MPa} \mathrm{H}_{2}, 5 \mathrm{~h}\right)$ 将菊芋根茎转化为六元醇, $1 \% \mathrm{Ru} / \mathrm{AC}$ 催化剂上六元醇收率为 $52.7 \%$, 而 $1 \% \mathrm{Ru} /\left(\mathrm{AC}^{\left.-\mathrm{SO}_{3} \mathrm{H}\right)}\right.$ 催化剂上可达 $84.1 \%$. 这归因于后者的酸强度和 $\mathrm{Ru}$ 分散度较大: 其表面的酸性基团 $-\mathrm{SO}_{3} \mathrm{H},-\mathrm{COOH},-\mathrm{OH}$ 促进了菊芋根茎的水解, 高分散度的Ru则促进了糖加氢反应的进行. 将Ru的负载量提高至 $3 \%$, 六元醇产率高达 $92.6 \%$.

以 $1 \% \mathrm{Ru} / \mathrm{AC}$ 和 $1 \% \mathrm{Ru} /\left(\mathrm{AC}-\mathrm{SO}_{3} \mathrm{H}\right)$ 为催化剂, 分别以果糖和菊粉为原料制备六元醇. 结果表明, 以果糖为原料时两种催化剂性 能相同; 以菊粉为原料时, $1 \% \mathrm{Ru} / \mathrm{AC}$ 的催化性能远低于 $1 \% \mathrm{Ru} /\left(\mathrm{AC}^{-} \mathrm{SO}_{3} \mathrm{H}\right)$. 这表明菊粉和菊芋根茎转化反应, 速控步骤是水解反 应, 而磺化过程引入的酸性基团可以促进水解过程的进行.

在 $\mathrm{N}_{2}$ 气氛下反应, 主要产物为果糖和葡萄糖, 表明菊芋根茎水解反应是主要的反应路径. 在 $\mathrm{H}_{2}$ 气氛下反应, 糖类产率在 $1 \mathrm{~h}$ 内 达到最大值, 然后开始逐渐降低, 同时加氢产物逐渐增加. 因此, $\mathrm{H}_{2}$ 气氛下反应过程中生成的糖类是中间产物.

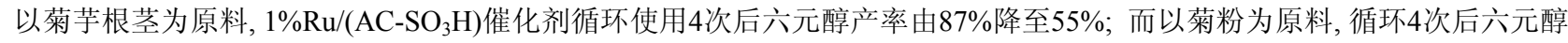
产率略有降低. ICP测试表明, Ru催化剂并未流失, 3次循环后催化剂的CO化学吸附表明, Ru的分散度由 $74.2 \%$ 降至 $17.8 \%$. 这表明 催化剂失活是由菊芋根茎中的杂质毒化Ru活性位点导致的.

关键词: 菊芋根茎; 六元醇; 双功能催化剂; 水解; 加氢; 钉; 磺化

收稿日期: 2015-04-17. 接受日期: 2015-06-03. 出版日期: 2015-10-20.

†共同第一作者

*通讯联系人. 电话: (0411)84379015; 传真: (0411)84691570; 电子信箱: taozhang@dicp.ac.cn

通讯联系人. 电话: (0411)84379348; 传真: (0411)84685940; 电子信箱: aqwang@dicp.ac.cn

现工作单位为中海油天津化工研究设计院.

基金来源：国家自然科学基金(21176235, 21306191, 21376239).

本文的英文电子版由Elsevier出版社在ScienceDirect上出版(http://www.sciencedirect.com/science/journal/18722067). 